ECONOMIC GROWTH CENTER

YALE UNIVERSITY

P.O. Box 208629

New Haven, CT 06520-8269

http://www.econ.yale.edu/ egcenter/

CENTER DISCUSSION PAPER NO. 906

\title{
Are Household Production Decisions Cooperative? Evidence on Pastoral Migration and Milk Sales from Northern Kenya
}

\author{
Cheryl R. Doss \\ Yale University \\ John G. McPeak \\ Syracuse University
}

February 2005

Notes: Center Discussion Papers are preliminary materials circulated to stimulate discussions and critical comments.

Financial support for this study was provided by an International Predissertation Fellowship from the Social Science Research Council and the American Council of Learned Societies with funds provided by the Ford Foundation, the Mellon Foundation, and the Graduate School of the University of Wisconsin-Madison. Work on the manuscript was conducted as a result of the authors' collaboration on the Pastoral Risk Management Project of the Global Livestock Collaborative Research Support Program, funded by the Office of Agriculture and Food Security, Global Bureau, USAID, under grants DAN-1328-G-00-0046-00 and PCE-G-98-00036-00. The opinions expressed do not necessarily reflect the views of the U.S. Agency for International Development. Doss: Yale Center for International and Area Studies, 34 Hillhouse Avenue, P.O. Box 208206, New Haven, CT 06520-8206, 203-432-9395; McPeak: Departments of Public Administration and Economics, 215 Eggers Hall, Syracuse University, Syracuse, NY 13244-1020, Fax: 315-443-9721, jomcpeak@maxwell.syr.ed

This paper can be downloaded without charge from the Social Science Research Network electronic library at: http://ssrn.com/abstract=668401

An index to papers in the Economic Growth Center Discussion Paper Series is located at: http://www.econ.yale.edu/ egcenter/research.htm 


\title{
Are Household Production Decisions Cooperative? Evidence on Pastoral Migration and Milk Sales from Northern Kenya
}

Cheryl R. Doss and John G. McPeak

\begin{abstract}
Market-based development efforts frequently create opportunities to generate income from goods previously produced and consumed within the household. Production within the household is often characterized by a gender and age division of labor. Market development efforts to improve well being may lead to unanticipated outcomes if household production decisions are non-cooperative. We develop and test models of household decision-making to investigate intra-household decision making in a nomadic pastoral setting from Kenya. Our results suggest that household decisions are contested, with husbands using migration decisions to resist wives’ ability to market milk.
\end{abstract}

Keywords: Intrahousehold decision-making, household production, Kenya JEL Codes: D13, O12 


\section{Introduction}

When new opportunities such as improved market access or new production technologies are introduced into societies, the nature of intra-household production decisions may affect the outcomes. Men and women frequently renegotiate their traditional roles and responsibilities with regard to production decisions in the advent of new opportunities. Some evidence, much of it descriptive and anecdotal, suggests that it may not be appropriate to model household decisions in response to new opportunities as cooperative decisions. Cooperative models may overlook the contested nature of intra-household decision making. Understanding the nature of such contestation is critical for those who seek to introduce new opportunities in the name of development. What appears to be a beneficial intervention under the assumption that households act cooperatively in adopting the new opportunity and distributing the benefits may instead have little impact or even lead to unforeseen adverse outcomes if decisions are contested.

Development efforts often focus on bringing goods that have been traditionally produced and consumed within the household into the market domain. As market institutions develop, new rules associated with the market must be reconciled with existing cultural institutions. In this study, we investigate intra-household production decisions for Gabra nomadic pastoralists who live in an arid climate in northern Kenya. Over the past thirty years, herders in northern Kenya have seen a rapid growth of milk marketing opportunities. What makes this situation intriguing is that the ability to market milk depends on the proximity to town. Among the Gabra, traditional cultural rules allocate the responsibility to decide where to locate the household to the husband. Households migrate frequently, as high spatial and temporal variability in rainfall requires moving the herds of cattle, camels, sheep and goats in search of pasture. In contrast to migration decisions, management of milk is traditionally the wife's domain. Milk marketing has 
been added relatively recently to milk management decisions. Marketing only takes place in the small market towns of the study area and requires trips on foot from the household location to the nearest market town. The nature of these decisions confers upon the husband "first mover" status unless he decides to participate in a decision making process where milk sales and migration decisions are made jointly. This allows analysis of these two decisions to provide unique insight into intra-household negotiation in the advent of a new market opportunity. Households may react to the new opportunities presented by the development of milk markets in four different ways. The first possibility is that a husband and a wife recognize economic benefits provided by the new market opportunity and make joint decisions on migration and milk marketing to maximize household welfare. We call this the joint cooperative solution, and it is characterized by the husband sacrificing his first mover status and participating in a decision making process that incorporates both the migration decision and a milk sales plan for the coming period. A second possibility is what we term the individual solution: in response to the new opportunity, the husband takes over milk marketing and decides on behalf of the household the migration decision and milk sales plan. ${ }^{1} \mathrm{~A}$ third possibility we describe as the traditional solution, where a husband continues to make migration decisions without considering the impact on milk marketing. The final possibility is that a husband views his wife's use of milk markets with trepidation, as milk marketing allows a wife to expand her traditional control over household milk to control cash income, potentially moving a component of household consumption to her private consumption. In this case, a husband may exploit his first mover status for the location decision to limit his wife's ability to market milk. We call this the contested solution. We formally model these outcomes below and then empirically investigate the pattern of household decision-making using panel data from Gabra pastoral households. 


\section{Empirical Literature on Cooperative and Noncooperative Outcomes}

Much of the literature on household decision-making assumes that households act cooperatively and examines which cooperative model, a unitary model or a bargaining model, best fits the data. ${ }^{2}$ The literature on intra-household consumption decisions is extensive. Studies that explicitly test for whether the assumptions of the cooperative model hold in consumption decisions tend to reach findings that reject the unitary model but do not reject Pareto efficiency as a characteristic of household decision making (Thomas et al., 2002; Thomas and Chen, 1993). Many studies use this finding to offer models of cooperative household decision making that do not rely on the unitary model and allow for different preferences and different weights or bargaining power of individuals to affect the outcomes (Quisumbing and Maluccio, 2003; Attanasio and Lechene, 2002; Hallman, 2001; Lundberg and Ward Batts, 2000; Doss, 1999; Lundberg et al., 1997). ${ }^{3}$

Studies examining risk sharing within households find less support for the assumption of cooperative decision making. Dercon and Krishnan (2000) find that poor households in southern Ethiopia do not engage in complete risk sharing; women in these households bear the brunt of adverse shocks. Doss (2001) finds that in Ghana shocks to men's and women's incomes have different effects on household expenditure patterns, suggesting that household members may be concerned about their individual long-term access to resources and that membership in a household is one way, but not the only way, to ensure this access. Both of these findings implicitly reject a cooperative model of the household.

Investigations of intra-household production decisions also tend to find less support for the cooperative decision making model. Udry (1996) uses detailed agronomic data from Burkina 
Faso and finds that crop yields are different on plots controlled by men from those controlled by women within the same household in a given year. He also finds that households could achieve higher total output by reallocating labor and fertilizer from men's plots to women's plots. Pareto efficiency would require that marginal productivity for an additional unit of labor or fertilizer be the same across all plots owned by the household. Thus, he rejects a cooperative outcome.

Similarly, Jones (1983) rejects the hypothesis of a cooperative outcome in her study of labor allocation following the introduction of irrigated rice production in Northern Cameroon. Both men and women continued to grow sorghum after irrigated rice was introduced, even though the returns to labor from rice production were higher. Men and women jointly cultivated the rice fields, whereas sorghum plots were individually cultivated. Reallocating labor from sorghum to rice would again have increased total household production. Von Braun and Webb (1989) and Dey (1981) present findings similar to Jones; the introduction of irrigated rice displaced women who had traditionally grown this crop in The Gambia as men took over rice cultivation. Women, in turn, began growing cotton and groundnuts, which were traditionally men's crops.

These examples highlight a common theme- the introduction of new production opportunities interacts with an existing gendered division of labor to lead to unforeseen outcomes. A variant of this theme considers the case of an existing product increasing in value when it enters the market domain. In this setting, production decisions may respond to new opportunities that may also challenge existing cultural definitions of the intra-household division of labor. A variety of studies in Africa consider the impact of increased milk marketing in pastoral areas, noting that the decisions about the management of milk, including milk marketing decisions, are made by women while herd management decisions, including migration, are made 
by men (Coppock 1994, Holden 1991, Bekure et al. 1991, Sikana and Kerven, 1991; Herren 1991, Ensminger 1987, Waters-Bayer 1985). The impact of the introduction of milk markets on household decision making varies across sites. Michael (1987) presents findings from the Sudan that are consistent with a cooperative outcome: men recognize the growing importance of milk marketing and adjust their migration decisions to incorporate this new opportunity. Ndagala's findings (1982) from Tanzania are consistent with the individual solution. In this case, when a market opportunity was introduced, men took control of milk marketing and the cash it generated. Evidence consistent with the contested model is provided by Waters-Bayer (1985) in Nigeria. In this setting, women control income from milk production and men are responsible for purchasing herd inputs (such as animal health services). This limits the adoption of milk production improving technologies, since the costs and benefits acrrue to different household members. Indirect evidence consistent with the contested model is also presented by Nduma et al. (2001): pastoral women in northern Kenya are less likely to market milk when a husband is present in the household, all else equal. ${ }^{4}$

Given this wide range of outcomes, we seek in this study to formalize the nature of the different types of outcomes. We contribute to the literature on this topic both by developing a simple but intuitive methodology to investigate intra-household patterns of decision making and presenting empirical evidence to support our findings.

\section{Gabra Pastoral Production}

Gabra are nomadic pastoralists living in northern Kenya and southern Ethiopia. Gabra inhabit an extremely arid and variable environment in which cultivation is not possible. Mean annual rainfall is below $300 \mathrm{~mm}$ for most of the Gabra rangelands. Rainfall is also highly 
variable, with a coefficient of annual variation of 0.55 at the center of the Gabra rangelands in North Horr. Gabra households share access to their grazing area and migrate throughout this area with their herds of camels, cattle, goats and sheep, in reaction to changing pasture conditions. They rely almost exclusively on their herds to meet their subsistence and income needs.

In Gabra culture, the husband has the right to decide when and where to move the household and the household herd. ${ }^{5}$ Such moves can be over extremely long distances. Traditionally, upon the husband's decision to migrate, the housing materials and all the household belongings are loaded onto camels and moved to the new location. It is the woman's responsibility to reconstruct the house when they reach the new location and the husband's responsibility to build new night enclosures for the animals from thorny bushes. They remain at this site until the husband decides the time has come to move again. The husband also makes decisions about splitting the herd. Gabra households frequently establish a satellite camp that usually moves male and non-lactating animals away from the milk herd kept at the base camp.

All things inside the hut are under control of the wife. Gabra symbolism is rich with contrasts between that which is inside the hut (female) with what is outside the hut (male). This is played out each evening in the ritual surrounding the milking of the herd. After the animals return from grazing, they are placed in their night enclosures and milked. The containers full of milk are then taken to the husband who sits outside the door of the hut. He inspects the milk, takes a ritual sip, and then passes it through the door into the hut where his wife receives it. When it passes into the hut, it becomes the wife's and it is her responsibility to manage it.

Traditionally, the management responsibility meant that the wife decided how much to use for each meal, how much to conserve as fermented milk or ghee, and how much to give away 
to other households. Increasingly, it means she decides how much of the milk will be marketed and how much will be consumed by the household. The marketing option has introduced a change in the nature of the management decision. Marketing allows the transformation of milk produced from the herd into cash. Women generally walk to town without their husband to participate in milk marketing. Thus, they have the opportunity to make independent decisions on how to spend this income before returning to the household. We investigate evidence on migration decisions and milk sales to investigate the outcome of intra-household negotiation over how to respond to this new market opportunity.

\section{Description of the Data}

This study uses longitudinal data gathered in two areas of Marsabit District, Kenya. Gabra pastoralists occupy the two areas studied: the Chalbi area and the Dukana area. The Chalbi area is drier than the Dukana area, but has more water points as it lies along the lowland Chalbi basin. Dukana is more remote and less served by transport; vehicles traveling to Dukana must first past through Chalbi. Markets are more active in Chalbi than in Dukana partially due to this difference in transport availability.

The sampling methodology used in this study is similar to a transect as no list of pastoral households existed for this area. Enumerators moved between the main towns of the study area (Kalacha and North Horr in Chalbi and Sabarei and Dukana in the Dukana area) interviewing herders they encountered at nomadic camps along the way. ${ }^{6}$ The questionnaire was retrospective in nature, recording information for four time periods per year for each of the years 1993-1997. ${ }^{7}$ Within a year, the four time periods correspond to the bimodal rainfall pattern of the area: the long rains, the dry season following these rains, the short rains, and the dry season following 
these rains. Each period is roughly three months in length. This approach provided multiple data points for a given household (from 16 to 20 data points, depending on when the household was interviewed in 1997 or early 1998). ${ }^{8}$ (see table one)

For each period, households reported the distance from the base camp to the nearest market town in the number of hours it took to walk this distance. They also reported the number of people and animals sent to a satellite camp if one was established. The distance between the base camp and town averaged just over five hours' walk in the Chalbi and over eight hours in Dukana. In both areas, roughly half of the households reported migrating and changing the distance from town from one three month period to the next.

Households also reported income sources, average daily milk production, and total milk sales per period. Almost all income is derived from livestock and livestock products. Assigning market values to home consumed goods reveals that the total value of marketed and home consumed income was the equivalent of $\$ 0.61$ per person per day in Chalbi and $\$ 0.38$ per person per day in Dukana. ${ }^{9}$ In Chalbi: $55 \%$ of household income is accounted for by home consumed milk produced by the household herd; $21 \%$ is obtained by home consumption of slaughtered animals; $20 \%$ is obtained by sale of animals; $3 \%$ is obtained by milk sales; and $1 \%$ is obtained by hide sales, gifts, and remittances. In Dukana: $82 \%$ of household income is accounted for by home consumed milk produced by the household herd; $9 \%$ is obtained by sale of animals; $8 \%$ is obtained by home consumption of slaughtered animals; $1 \%$ is obtained by milk sales; and less than $1 \%$ is obtained by hide sales, gifts, and remittances. Milk sales accounted for $11 \%$ of household cash income on average in Chalbi and 14\% in Dukana. The majority of households, $67 \%$ of households in Chalbi and $86 \%$ in Dukana, sold milk during one or more seasons between 1993 and 1997. The price of milk was constant over the study period at a price of 20 shillings 
per liter in both sites. Median milk production per day ${ }^{10}$ in the Chalbi area was 4.5 liters per household per day, $34 \%$ of which came from camels, $5 \%$ from cattle, and $61 \%$ from sheep and goats. In Dukana the corresponding figure are 3.5 liters per household per day, 21\% from camels, $26 \%$ from cattle, and $53 \%$ from sheep and goats.

Respondents were asked to report the following variables for each time period: ages of household members; household size; starting period household herd size; and species composition. Household size was converted into an adult equivalent scale following the method outlined by Martin (1985). ${ }^{11}$ Variables recording herd size are converted to total livestock units (TLU), following the method of Schwartz et al. (1991). ${ }^{12}$ The median Chalbi household had six residents (4.5 adult equivalents) while the median Dukana household had five residents (4.3 adult equivalents). The median herd size per species in Chalbi was: 9 camels, 2 cattle, and 193 sheep and goats. In Dukana the corresponding figures are: 4 camels, 5 cattle, and 58 sheep and goats.

The data set also records variables exogenous to the household. Monthly rainfall data was gathered at the North Horr Catholic mission and the Kalacha African Inland Church mission Both rainfall collection sites were in Chalbi; no rainfall data was available for Dukana, although we would expect the patterns to be similar. The rainfall variable is constructed as the average of these two sites for a given season. Three variables are used to record rainfall characteristics of a given time period; one measures total rainfall in the current three-month period plus the last three-month period as this corresponds to the effective growing season for pasture in this bimodal rainfall system, and two dummy variables record whether the period in question is a rainy season. A variable records the tons of food aid delivered to the towns of the study area in a given time period and is constructed from data gathered at the above mentioned missions which 
are also food aid distribution points. ${ }^{13}$ Table 1 presents summary statistics of variables used in later regressions.

\section{Models of Household Decision Making}

We develop three static models of intra-household decision making in this section that correspond to different decision making scenarios. ${ }^{14}$ In each model, the household members are confronted with a decision about how much milk to sell and where to locate the household. ${ }^{15}$ There is a clear difference in the nature of the timing associated with the actions that result from these decisions. The location decision is a made at the start of a period and implemented over at most a few days, and characterizes the distance a household will reside from town for a three month period. Milk marketing takes place as multiple round trips throughout the period between the household to the nearest town. We place these two decisions on the same time scale by viewing the observed milk marketing behavior as the implementation of a seasonal "milk marketing plan" that is chosen at the start of the period and implemented over the entire period. This plan specifies the amount of milk that the household will market during a given three month period. In the cooperative model, this "milk marketing plan" is selected jointly with the distance decision. In the traditional model, the distance decision is made ignoring the existence of a plan. In the contested model, this plan is conceived of as the wife's best response function. The specification of the traditional and the contested models rely on the fact that the temporal nature of the decisions allows the husband "first mover" status should he choose to make decisions noncooperatively.

\section{A) Cooperative Decision Making}


In this model, the household decides on the distance to settle from town and the milk sales level in a cooperative manner. Here, we model it as a joint decision by the husband and wife. This can be viewed as the outcome of a family meeting, where the husband and wife discuss the implications of various decisions prior to the opening of a period, and jointly choose a distance from town and the milk marketing plan for the coming period to maximize household utility. We are not concerned here with the process of household-decision making, but rather with the outcomes, which are observable.

For our purposes, the results derived from this model and the individual model, where the husband takes over the milk marketing and makes both sales and distance decisions himself, are the same. ${ }^{16}$ In either case, the outcome maximizes the joint household separable utility function. The distribution of this utility may vary across the two models, but we are not able to examine this. For both the husband and wife, define a logarithmic utility function. Utility is an increasing and concave function of consumption. Total household utility is obtained by summing the utility of the husband and the wife. Consumption is defined as a household good that is shared proportionally by the husband and wife according to the parametrically defined weighting shares $\alpha$ and $1-\alpha \cdot{ }^{17}$ Therefore total household utility is defined by

$$
\mathrm{U}(\mathrm{c})=\ln (\alpha \cdot \mathrm{c})+\ln ((1-\alpha) \cdot \mathrm{c})
$$

The first component on the right hand side reflects the husband's utility function and the second is the wife's. Total household consumption (c) includes milk consumed by the household members and goods purchased with the income from milk sold. ${ }^{18}$ The value of milk in home consumption can be viewed as the numeraire good so that the relative value of goods purchased by milk sales to the value of milk in home consumption is defined by $\theta .{ }^{19}$ Total milk production is $\mathrm{m}$, milk sales occur at price $\mathrm{p}$, and the quantity of milk sold is represented by $\mathrm{s}$ which is 
assumed to be in the interval $[0, \mathrm{~m}]$. The total level of consumption available to the household can be represented as $\mathrm{c}=(\mathrm{m}-\mathrm{s})+\theta \cdot \mathrm{p} \cdot \mathrm{s}$.

The distance from town to the household location is represented by d. Milk markets are located in towns. Therefore, the labor effort involved with marketing milk is an increasing function of milk sales and distance from town. Assume the labor cost of milk marketing can be represented by a multiplicative specification with a parameter $\omega_{1}$ assigning a parametric weight on milk marketing labor. Thus the disutility of milk marketing labor effort can be represented by $-\omega_{1} \cdot \mathrm{s} \cdot \mathrm{d}$.

Towns also are the centers of amenities, such as health centers, schools, news and communication centers, bars and restaurants, public security, and markets for consumption goods. Therefore, settling further from town provides disutility by reducing household members' ability to access these amenities. Assume the household shares the benefits and household members agree on the weight of the benefits provided by town based amenities, and assign them a weight equal to $\omega_{2}$. However, as other herders also desire to be near town to take advantage of these amenities, the necessary labor effort for herding increases the closer one settles to town, at a disutility weight of $\omega_{3}$. As males are generally responsible for herding tasks, this can be seen as a reflection of the husband's labor - leisure tradeoff. We specify this disutility component as an inverse function of distance to reflect the gradient of grazing pressure around a fixed point such as a town. We can represent these two countervailing influences that bring disutility by $-\omega_{2} \cdot d-\left(\frac{\omega_{3}}{d}\right)$.

The household thus solves the following problem. 


$$
\underset{\mathrm{s}, \mathrm{d}}{\operatorname{Max}} \ln (\alpha \cdot(\mathrm{m}-\mathrm{s}+\theta \cdot \mathrm{p} \cdot \mathrm{s}))+\ln ((1-\alpha) \cdot(\mathrm{m}-\mathrm{s}+\theta \cdot \mathrm{p} \cdot \mathrm{s}))-\omega_{1} \cdot \mathrm{s} \cdot \mathrm{d}-\omega_{2} \cdot \mathrm{d}-\frac{\omega_{3}}{\mathrm{~d}}
$$

The joint solution of this problem provides the following conditions:

$$
\begin{aligned}
& d=\left(\frac{\omega_{3}}{\omega_{2}+\omega_{1} \cdot s}\right)^{\frac{1}{2}} \\
& s=\left(\frac{1}{\omega_{1} \cdot d}\right)-\left(\frac{m}{\theta \cdot p-1}\right)
\end{aligned}
$$

Thus, in the cooperative model, the two decisions are made simultaneously and each depends on the other. Households choose the distance from town as a decreasing function of milk sales. Households choose milk sales as a decreasing function of distance.

\section{B) The Traditional Model.}

In this model, we assume that the husband makes the location decision without considering how this influences milk sales. His first mover status is granted by the by reference to cultural precedent that gives him exclusive right to base mobility decisions on what is in the best interest of the herd and family. There is no such cultural precedent for basing decisions on the implications for milk marketing. The household does not jointly decide the distance and milk marketing program for the coming period in this model. The husband acts by making the location decision and the wife takes the location decision as given and then decides how much milk to sell. Although we did not find any discussion of such a model in the literature, it was a description of the decision making process proposed by Gabra respondents during our fieldwork. It can perhaps best be thought of as an initial stage of reaction to the introduction of a new market, when households are sorting out what to make of this new opportunity while still operating under existing cultural rules. 
Assume the husband views decisions about milk marketing as his wife's concern and does not pay attention to the implication of his distance decision for her ability to market milk. The husband chooses the household location based on his own considerations of the tradeoff between town based amenities and increased labor effort for herding near town:

$$
\operatorname{Max}_{d} \ln (\alpha \cdot(m-s+\theta \cdot p \cdot s))-\omega_{2} \cdot d-\omega_{3} \cdot\left(\frac{1}{d}\right)
$$

while his wife takes the distance as given and solves:

$$
\operatorname{Max}_{\mathrm{s}} \ln ((1-\alpha) \cdot(\mathrm{m}-\mathrm{s}+\theta \cdot \mathrm{p} \cdot \mathrm{s}))-\omega_{1} \cdot \mathrm{s} \cdot \mathrm{d}
$$

The solutions to these problems are

$$
\mathrm{d}=\left(\frac{\omega_{3}}{\omega_{2}}\right)^{\frac{1}{2}}
$$

and

$$
s=\left(\frac{1}{\omega_{1} \cdot d}\right)-\left(\frac{m}{\theta \cdot p-1}\right)
$$

This model indicates that distance is determined independently of milk sales and the milk sales decision is a decreasing function of distance. Assuming sales are non-zero, contrasting equation (3) to equation (7) indicates that distance from town will be higher under the traditional model than the cooperative model. As equations (4) and (8) are identical, a higher distance from town implies a lower level of milk sales in the traditional model compared to the cooperative model. This suggests that there are internal forces within the traditional model that would lead it to break down over time, as husbands begin to realize that higher consumption and utility are available by recognizing the role of women's milk marketing in overall household consumption and incorporating the potential for milk sales into the location decision. 
C) The Contested Model.

In this model, we allow for the husband to understand that the introduction of milk marketing has created a new decision-making context. However, rather than seeing the benefits and moving to a cooperative outcome as described in the paragraph above, the husband instead views this new opportunity as presenting a threat. He sees the marketing opportunity as a way for his wife to convert milk that was in joint household consumption into income that is under her sole control. ${ }^{20}$ In this situation, the husband realizes that his power as first mover allows him some leverage to manipulate his wife's milk sales. Assume that some fraction of the milk sales income, $\eta$, is devoted to the household consumption bundle, while the remainder $(1-\eta)$ is allocated to consumption that enters only the consumption of the wife, so that the husband's consumption is $\alpha \cdot(\mathrm{m}-\mathrm{s}+\theta \cdot \mathrm{p} \cdot \mathrm{s} \cdot \eta)$ while the wife's is $(1-\alpha) \cdot(\mathrm{m}-\mathrm{s}+\cdot \theta \cdot \mathrm{p} \cdot \mathrm{s} \cdot \eta+\cdot \theta \cdot \mathrm{p} \cdot \mathrm{s} \cdot(1-\eta))$ which can be expressed more simply as $(1-\alpha) \cdot(m-s+\theta \cdot p \cdot s)$ since she gets the benefits of the milk proceeds that are represented in shared household consumption as well as those that now enter as her private consumption. As the milk sales lead to less milk in shared consumption and more used for the wife's exclusive consumption, it may be in a husband's interest to reduce his wife's incentive to sell milk. Men solve the following problem:

$$
\operatorname{Max}_{d} \ln (\alpha \cdot(m-s+\theta \cdot p \cdot s \cdot \eta))-\omega_{2} \cdot d-\frac{\omega_{3}}{d}
$$

while the wife is faced with the problem

$$
\operatorname{Max}_{\mathrm{s}} \ln ((1-\alpha) \cdot(\mathrm{m}-\mathrm{s}+\theta \cdot \mathrm{p} \cdot \mathrm{s}))-\omega_{1} \cdot \mathrm{s} \cdot \mathrm{d}
$$

As the nature of these decisions gives the husband first mover status, we can solve this problem recursively. We begin with the wife's maximization problem recorded in equation (10), 
for which the first order condition is the same as reported in equation (8). Substituting the wife's best response function into the husband's decision problem gives us the following.

$$
\operatorname{Max}_{d} \ln \left(\alpha \cdot\left(m+\left[\frac{1}{\omega_{1} \cdot d}-\frac{m}{\theta \cdot p-1}\right] \cdot(\eta \cdot \theta \cdot p-1)\right)-\omega_{2} \cdot d-\frac{\omega_{3}}{d}\right.
$$

Solving this problem gives us the following condition.

$$
\mathrm{d}=\left(\frac{\omega_{3}}{\omega_{2}}+\left(\omega_{1} \cdot \omega_{2} \cdot\left(\mathrm{m}-\mathrm{s}^{*}+\eta \cdot \theta \cdot \mathrm{p} \cdot \mathrm{s}^{*}\right)^{-1}\right)^{\frac{1}{2}}\right.
$$

where the best response milk sales function $\mathrm{s}^{*}$ is,

$$
\mathrm{s}^{*}=\left(\frac{1}{\omega_{1} \cdot \mathrm{d}}\right)-\left(\frac{\mathrm{m}}{\theta \cdot \mathrm{p}-1}\right)
$$

As in the other cases considered, milk sales are a decreasing function of distance. In this case, distance is a decreasing function of milk sales when $\eta \cdot \theta \cdot p>1$ and an increasing function of milk sales when $\eta \cdot \theta \cdot p<1$. While we are assuming $\eta$ is fixed for simplicity, equation (12) suggests an intuitive result: selecting lower values of $\eta$ leads to a greater distance from town than obtained at higher values of $\eta$. This suggests that a wife could select $\eta$ to compensate her husband for the loss of milk by increasing overall household consumption and still capture some of the benefits for her own personal consumption. However, consider the worst case scenario from the husband's standpoint, the case of $\eta=0$. If the wife is able to use the presence of a milk market to completely transform a shared household consumption good into a consumption good that only enters her utility, the husband will use the status conferred to him by the nature of the production decisions to resist her efforts to market milk. This basic insight will characterize all decisions under the condition that $\eta \cdot \theta \cdot p<1$. The comparison of the three models is summarized in table 2 . 
These findings suggest we should expect the milk sales variable to be always decreasing in distance. The distinction between the three models depends on the sign and the significance of the milk sales parameter in the equation for distance. The contested and the cooperative models will only be possible to distinguish when certain conditions hold for parameter values. These results provide the foundation for the empirical estimations that follow.

\section{Empirical Analysis}

In this section, we use observed values for the distance a household settles from town in a given period and the total amount of milk sold in the period to investigate the relationship between these decisions. We estimate these two decision variables jointly. Denoting the distance from town decision by $\mathrm{d}$, the milk sales decision by $\mathrm{s}, \gamma$ and $\beta$ as parameters to be estimated, $\mathrm{X}$ as matrices of exogenous variables, and $\mathrm{u}$ as underlying disturbance terms, the following two equation system is defined:

$$
\begin{aligned}
& d=\gamma_{s} \cdot s+\beta_{d} X_{d}+u_{d} \\
& s=\gamma_{d} \cdot d+\beta_{s} X_{s}+u_{s} \\
& u_{d}, u_{s} \sim \operatorname{BVN}\left(\sigma_{d}^{2}, \sigma_{s}^{2}, \rho\right)
\end{aligned}
$$

The parameter of interest is the sign and significance of $\gamma_{s}$ in the distance equation. If estimation reveals it to be negative and significant, this indicates an outcome of a decision making process that is consistent with the cooperative model or the contested model when $\eta \cdot \theta \cdot p>1$ (the wife "pays off" the husband so that he is willing to move closer to town.). ${ }^{21}$ If it is not significantly different from zero, the outcome is consistent with the traditional model. Finally, if we find it to be positive and significant, this provides an outcome consistent with the contested model when the share of the proceeds to the husband is not great enough to make him move closer to town. 
The simultaneous equation specification (14) nests the three models introduced above. We model the two decisions as taking place jointly as they both take place within a given season. As discussed above, there are four distinct seasons per year. A location decision and a milk sales plan are made in response to the same set of information revealed at the start of the season. If the two decisions are made at the same moment within the period, as in the cooperative model where the husband and wife decide on a plan for the season, equation (14) holds as written under the assumption that the observed milk sales behavior is the implementation of the jointly defined seasonal milk marketing plan. If the traditional structure holds, the model is recursive so that $\gamma_{\mathrm{s}}=0$ meaning that husbands decide the distance without concern about the impact on milk sales, and the milk sales plan is defined in response to this distance decision. This specification corresponds to the special case of a simultaneous equations model that Greene terms triangular (p. 582). Finally, if the contested model holds, equation (14) remain as written under the assumption that the observed behavior is the implementation of a wife's best response milk sales plan defined in reaction to a husband's distance decision.

Four issues emerge when attempting to estimate this system of equations. First, both dependent variables are by construction non-negative and censored at zero. ${ }^{22}$ Distance from town equals zero for $7 \%$ of observations in Chalbi and 3\% in Dukana. In addition, no milk was sold for $72 \%$ of total observations in Chalbi and $82 \%$ in Dukana. ${ }^{23}$ Failure to take account of the censored nature of dependent variables results in inconsistent parameter estimates. As the equations are specified as a system, the methodology used is full information maximum likelihood estimation of a bivariate tobit system (Maddala, 1982).

A second issue arises due to the longitudinal nature of the panel data. It is possible that there are underlying household specific characteristics that influence distance and milk sales 
decisions. If not controlled for, the presence of such characteristics will lead parameter estimates to be inconsistent (Hsiao, 1986). To address this issue, a time invariant household specific fixed effect is controlled for by creating a matrix recording the means of household specific variables for all time periods observed ${ }^{24}$ and using simulation methods to control for a household specific random effect that is uncorrelated with the observed means (Gourieroux and Monfort,1993).

Third, as has been noted, there are significant differences between the two study areas in terms of production and market conditions. To allow for parametric differences between the sites, estimations are conducted separately for the Chalbi and the Dukana data.

Finally, to identify the endogenous variables in the system, we need at least one variable that affects location but not milk sales and at least one variable that affects milk sales but not distance. We include in the estimation three variables that were logically related to one dependent variable but not the other. Included in the distance equation are variables recording whether a raid occurred anywhere in the rangelands during the period and the number of pack camels owned by the household, as it was suggested during our survey work that these factors influenced migration decisions. Since raids are events that move households closer to town to be nearer security forces and other herders for self defense, and pack camels are used to load and move households, we expect that, all else equal, a raid causes households to move closer to town and increased access to pack camels allow a household to settle further from town. To identify the milk sales equation, we constructed a variable that records the average value of milk sold by other households in the sample for a given study site in the period. As women generally walk the long distance to town and back in small groups, we expect this variable to be positively related to sales: all else equal, more sales will occur when there is more likelihood of company with whom to pass the time on the long walk. These results are presented in table three. 
Unfortunately, the three variables selected for identification are not statistically significant, either individually or jointly $\left(\chi_{(3)}^{2}=1.8\right.$ in Dukana and $\chi_{(3)}^{2}=0.9$ in Chalbi).

However, the results of this estimation suggest a modification of the approach to identification of the endogenous variables based on exclusion restrictions defined for the age variables for the decision maker's spouse. ${ }^{25}$ We reestimate the model with these exclusion restrictions defined to augment the three exclusion restrictions described above and present the results in table four. Likelihood ratio tests indicate there is not a statistically significant difference between the alternative model specifications in Dukana $\left(\chi_{(4)}^{2}=1.0\right)$ or Chalbi $\left(\chi_{(4)}^{2}=2.7\right)$, and the joint significance of the identifying restrictions is now statistically significant. ${ }^{26}$ Comparison of the results in tables two and three suggests there are only minor differences between estimated parameters with and without the age variable exclusion restrictions. We will confine our discussion to the results in table four as identification is less of a concern when the age variable exclusion restrictions are imposed.

The results for the endogenous parameters satisfy the coherency condition described by Maddala (1982) in all results presented. The results show that the coefficient on milk sales in the distance estimation is positive and significant in all versions of the model estimated, thereby providing results consistent with the contested model of the household. As expected, the coefficient on distance in the milk sales estimation is negative and significant in most versions of the model estimated. As distance increases, milk sales decrease. The quantitative impact can be seen by simulating estimation results at sample means. The elasticity of distance with respect to milk sales is 0.1 in Dukana and 0.5 in Chalbi. The elasticity of milk sales with respect to distance is -2.8 in Dukana and -0.1 in Chalbi. From another perspective, a one liter increase in milk sales corresponds to a $6 \%$ increase in predicted distance in Dukana and a $2 \%$ increase in 
Chalbi. A one hour increase in distance corresponds to a $27 \%$ reduction in predicted milk sales in Dukana and a 2\% reduction in Chalbi. One interpretation of these results is that contestation over decisions may be more pronounced when the market is small and more recently introduced, as is the case in Dukana compared to Chalbi.

Some of the other estimation results merit discussion. All estimations indicate that distance from town is a decreasing function of male age and milk sales are an increasing function of female age. The variables for the husband's age are significant in the distance equation for all estimations. The female age variables are not statistically significant in the Dukana milk sales equation and are significant at the $10 \%$ level in the Chalbi estimation, suggesting identification could still be an issue in the milk sales estimation results. Husbands may be more interested in town based amenities as they age and their families grow, and wives may gain in status and power within the household as they age and may be more able to participate in milk marketing as child care tasks become less arduous at the base camp. The pack camel, raid dummy variables, and milk sales by others variables are not individually or jointly significant in either estimation.

The lagged dependent variables indicate that there is a positive association between the lagged value of the dependent variable and the current period value, and this impact is statistically significant with the exception of milk sales in Dukana. The results for the lagged variable for distance can be understood as there is a fixed cost to moving in terms of labor, and roughly half of households do not move from one period to the next. The milk sales results indicate that once a household is active in marketing milk, they tend to continue for more than one season, although this is again only significant in the Chalbi results. The sites present contrasting results for the impact of the signs of the lagged value of one dependent variable on the current period value of the other dependent variable. In Chalbi both effects are negative and 
significant, while in Dukana lagged sales is positively and significantly associated with current period distance. One possible explanation for this difference is that there are very few non-zero observations for lagged sales in Dukana compared to Chalbi due to differences in seasonality of marketing, suggesting caution in interpreting the Dukana results is needed. Milk production and marketing are more influenced by seasonality in Dukana than in Chalbi as seen in tables 4 and 5 . Direct analysis of the data set indicates average rainy season milk sales in Dukana are 53 shillings, while dry season sales average 5 shillings. In contrast, Chalbi rainy season sales average 383 shillings, and dry season sales average 435 shillings. Corresponding to this pattern, only $2 \%$ of observations in Dukana indicate households sold milk it two consecutive periods compared to $17 \%$ of observations in Chalbi. For the Chalbi results, we interpret the results for the lags of the cross-dependent variables as reflecting "types" of households. Those who market milk in multiple periods are the type that has adopted this new innovation and may be cooperative, masked within the overall pattern of noncooperation. We pick up on this in the lag of sales in distance, but their potential cooperation in current period is overwhelmed by the larger proportion of non-cooperative household types. Similarly, those residing far from town in last period and this period are a type less likely to be market involved, since they stay far from town, thus explaining the sign of the parameter on last period's distance in the sales equation. Household size has a significant impact on distance from town in Dukana, and on milk sales in Chalbi. Increased food aid deliveries decrease distance from town, but have no impact on milk sales. Food aid is usually delivered to the towns and thus food aid deliveries provide an incentive for people to locate closer to town. The food aid result presents an interesting contrast to the milk marketing result. As food aid enters joint household consumption, it appears that men are willing to adjust location decisions to ease their ability to access food aid. This contrasts with 
their behavior in response to milk sales that move milk out of home consumption and into income controlled by their wives. Decisions made about the use of this income have an uncertain impact on home consumption and increase a wife's autonomy. Rainfall only has a significant impact on distance from town in Chalbi, and the seasonal dummy variables when significant indicate that rainy seasons lead households to be closer to town and to sell more milk, with the exception of the second rainy season in Chalbi. As the rainfall variable reflects data collected in the Chalbi area (Dukana data was not available), this could explain the lack of significance of the rainfall measure in Dukana. The herd size variables are not statistically significant in the estimation of either location or milk sales decisions in Chalbi. It appears that wealth in livestock is not a major determinant of household distance from town or milk sales in this area.

Two alternative explanations to the contested decision making hypothesis could explain the observed pattern of the endogenous coefficients and should be considered. First, it could be the case that the positive coefficient for milk sales in the distance equation reflects cooperative behavior as a move further from town increases milk production, thus increasing the availability of milk to sell. This would be the case if milk production is an increasing function of distance from town. We investigate this possibility by conducting fixed effects estimation of the milk production data presented in table five. We find no significant impact on milk production that can be attributed to the distance a household settles from town in Chalbi, and in Dukana milk production decreases as distance to town increases up to fourteen hours away from town. This latter result could reflect the fact that water points in the Dukana area are few and far between and located in towns, compared to the low-lying Chalbi basin that has multiple water sources 
away from towns, so that increased distance from town also leads to increased distance from water for animals (up to some point where one becomes closer to an alternative watering point).

A second alternative interpretation of our results recognizes that the distance a household settles from town and the use of a satellite camp are to some degree substitutes (McPeak, 2003). By moving further from town, a household is able to occupy less crowded pastures and allow for the satellite herd to rejoin the base camp herd. This could also explain the observed results in a way that is cooperative, rather than contested. This is not likely to be the explanation, as satellite animals tend to be composed of male and non-lactating animals in this area while milk herds are kept at the base camp with the family. However, we can not reject this hypothesis directly given data limitations.

\section{Conclusion}

The results are consistent with a contested model of household decision-making. Men appear to be making decisions about the distance from town in order to limit women's ability to market milk. This result is consistent with the notion that men resist the ability of their wives to move milk from current cultural institutions into the market domain. While there may be benefits to increased milk marketing in this area, our results suggest men are reluctant to facilitate this increase, possibly because they do not gain the benefits.

Is this contestation a good thing or a bad thing for overall household welfare? We do not have the data to adequately address this issue in this context. Some studies indicate that income in women's control is more likely than men's income to be spent on goods for children (Hoddinott and Haddad, 1995; Thomas, 1993). This would suggest that children's welfare will increase when women earn income from milk sales. On the other hand, by selling milk, women 
are also reducing the amount of milk available to the household, though potentially increasing caloric availability. As noted on the literature on pastoral sedentarization, there is a clear link between child malnutrition and lack of access to milk (Fratkin et al., 1999). Thus, the impact on children is ambiguous. We leave as a topic for further study who is "right" in this case; husbands who resist milk marketing or wives who wish to expand it.

What we can say is that husbands and wives are responding to the new opportunity brought about by milk marketing in this area in a way that appears non cooperative. While the verbal description most often encountered in our field work matched the traditional model, the evidence we find suggests the most appropriate way to understand the process is one of contestation. Husbands are using their traditional right to decide migration patterns to reduce wives sales', and do not appear to view the benefits they are getting from this new marketing opportunity to be large enough to move towards a more cooperative model of decision making. Wives are asserting that their traditional right over milk management extends to this new setting. This finding suggests that the introduction of market opportunities for goods that are traditionally home consumed may meet with resistance within the household.

The production context, model, and statistical approach outlined in this study provide an intuitive and straightforward way of understanding how households react to new market opportunities when there is a gendered division of labor in household production. Moving what has been a home produced and consumed good into the market domain may have unforeseen consequences if the presumption is that households cooperatively will make decisions to benefit from the new market opportunity. As development strategy increasingly relies on using markets to accelerate development (USAID, 2004; USAID, 2002; World Bank, 2001), we suggest that market development efforts can be improved by recognizing the potential for intra-household 
contestation over production decisions in the advent of new market opportunities. While much remains to be understood about the dynamics of response to new market opportunities, we present this study as a step towards developing a more profound understanding of how households will react the introduction of new market opportunities. 
Table 1. Descriptive Statistics

\begin{tabular}{|c|c|c|c|c|}
\hline Variable & $\begin{array}{l}\text { Chalbi } \\
\text { Mean }\end{array}$ & $\begin{array}{c}\text { Chalbi } \\
\text { Standard } \\
\text { Deviation }\end{array}$ & $\begin{array}{c}\text { Dukana } \\
\text { Mean }\end{array}$ & $\begin{array}{c}\text { Dukana } \\
\text { Standard } \\
\text { Deviation }\end{array}$ \\
\hline $\begin{array}{l}\text { Distance --base camp to town (hours } \\
\text { walk) }\end{array}$ & 5.12 & 4.78 & 8.27 & 8.22 \\
\hline $\begin{array}{l}\text { Value of Milk Sales (liters per period * } \\
20 \text { shillings per liter) }\end{array}$ & 420.11 & 856.39 & 29.27 & 70.05 \\
\hline Milk Production (liters per day) & 5.21 & 4.41 & 3.71 & 2.19 \\
\hline Herd size in TLU & 42.67 & 31.13 & 18.66 & 6.84 \\
\hline Household size in Adult Equivalents & 5.04 & 2.17 & 4.68 & 1.77 \\
\hline Percent or periods satellite camp used & 47.71 & 49.98 & 43.82 & 49.63 \\
\hline Rainfall in mm over past six months & 58.39 & 42.09 & 65.53 & 47.57 \\
\hline Long Rains Dummy & 0.27 & 0.45 & 0.25 & 0.43 \\
\hline Short Rains Dummy & 0.24 & 0.43 & 0.25 & 0.43 \\
\hline Food aid deliveries in tons per period & 72.37 & 88.97 & 65.22 & 85.74 \\
\hline Age of oldest male in household & 47.13 & 14.33 & 53.12 & 12.09 \\
\hline Age of oldest female in household & 36.84 & 13.24 & 36.50 & 10.04 \\
\hline Number of Observations & \multicolumn{2}{|c|}{677} & \multicolumn{2}{|c|}{980} \\
\hline Number of Households & \multicolumn{2}{|c|}{39} & \multicolumn{2}{|r|}{49} \\
\hline
\end{tabular}

${ }^{a}$ Note that the price of milk was constant at 20 shillings per liter over the entire period. 
Table 2. Summary of Model Predictions

\begin{tabular}{|l|l|l|l|}
\hline & $\begin{array}{l}\text { Cooperative } / \\
\text { Individual }\end{array}$ & Traditional & Contested \\
\hline $\begin{array}{l}\text { Distance } \\
\text { Variable }\end{array}$ & Decreasing in $\mathrm{s}$ & $\begin{array}{l}\text { Not a function of } \\
\mathrm{s}\end{array}$ & $\begin{array}{l}\text { Increasing in s when }(\eta \cdot \theta \cdot \mathrm{p}<1), \\
\text { decreasing in s otherwise }\end{array}$ \\
\hline $\begin{array}{l}\text { Milk Sales } \\
\text { Variable }\end{array}$ & Decreasing in $\mathrm{d}$ & Decreasing in $\mathrm{d}$ & Decreasing in $\mathrm{d}$ \\
\hline
\end{tabular}


Table 3. SFIML Simultaneous Tobit Estimation of Distance from Town and Milk Sales.

\begin{tabular}{|c|c|c|c|c|}
\hline & \multicolumn{2}{|c|}{ Dukana } & \multicolumn{2}{|c|}{ Chalbi } \\
\hline & Distance & Milk Sales $\left(\times 10^{-2}\right)$ & Distance & Milk Sales $\left(\times 10^{-3}\right)$ \\
\hline Milk sales & $\begin{array}{l}3.23728 * * * \\
(0.666749) \\
\end{array}$ & & $\begin{array}{l}3.70409 * * * \\
(0.260327) \\
\end{array}$ & \\
\hline Distance & & $\begin{array}{l}-0.599072 * \\
(0.341701)\end{array}$ & & $\begin{array}{l}-0.595719 * * \\
(0.242213)\end{array}$ \\
\hline Number of pack camels & $\begin{array}{l}-0.572128 \\
(0.654798)\end{array}$ & & $\begin{array}{l}-0.137171 \\
(0.226629)\end{array}$ & \\
\hline Raid dummy & $\begin{array}{l}-0.0492209 \\
(0.191910)\end{array}$ & & $\begin{array}{l}-0.172110 \\
(0.409329)\end{array}$ & \\
\hline $\begin{array}{l}\text { Average milk sales by others } \\
\left(\mathrm{x} 10^{-3}\right)\end{array}$ & & $\begin{array}{l}1.23990 \\
(1.13093)\end{array}$ & & $\begin{array}{l}0.686253 \\
(0.919031)\end{array}$ \\
\hline Constant & $\begin{array}{l}14.4247 * * \\
(6.60544)\end{array}$ & $\begin{array}{l}-21.4499 * * * \\
(6.05311)\end{array}$ & $\begin{array}{l}-8.35751 * * \\
(3.97298)\end{array}$ & $\begin{array}{l}-0.559989 \\
(3.78105) \\
\end{array}$ \\
\hline Distance last period & $\begin{array}{l}0.459457 * * * \\
0.0359145 \\
\end{array}$ & $\begin{array}{l}0.177820 \\
(0.136639)\end{array}$ & $\begin{array}{l}0.449358 * * * \\
0.0510154 \\
\end{array}$ & $\begin{array}{l}-0.112555 * * * \\
(0.041646)\end{array}$ \\
\hline Sales last period & $\begin{array}{l}0.954528 * * \\
(0.469593) \\
\end{array}$ & $\begin{array}{l}0.130648 \\
(1.15996) \\
\end{array}$ & $\begin{array}{l}-1.34803 * * * \\
(0.301940) \\
\end{array}$ & $\begin{array}{l}0.706322 * * * \\
(0.191056) \\
\end{array}$ \\
\hline Herd size in TLU $\left(\times 10^{-1}\right)$ & $\begin{array}{l}-0.959531 \\
(1.00141) \\
\end{array}$ & $\begin{array}{l}1.39487 * \\
(0.718831)\end{array}$ & $\begin{array}{l}0.111233 \\
(0.112325)\end{array}$ & $\begin{array}{l}-0.001784 \\
(0.036506)\end{array}$ \\
\hline $\begin{array}{l}\text { Household size in adult } \\
\text { equivalents }\end{array}$ & $\begin{array}{l}1.63187 \\
(1.15071) \\
\end{array}$ & $\begin{array}{l}2.97923 \\
(4.97837) \\
\end{array}$ & $\begin{array}{l}-1.42609 * \\
(0.756399)\end{array}$ & $\begin{array}{l}0.333106 \\
(0.275132)\end{array}$ \\
\hline Food aid in tons $\left(\times 10^{-2}\right)$ & $\begin{array}{l}-1.16293 \\
(0.747377)\end{array}$ & $\begin{array}{l}1.03906 \\
(1.15768)\end{array}$ & $\begin{array}{l}-0.700682 * * \\
(0.343547)\end{array}$ & $\begin{array}{l}-.014866 \\
(.322139) \\
\end{array}$ \\
\hline $\begin{array}{l}\text { Rainfall in mm in past six } \\
\text { months }\left(\times 10^{-2}\right)\end{array}$ & $\begin{array}{c}-0.04204 \\
(0.271875)\end{array}$ & $\begin{array}{l}0.681842 \\
(1.78415) \\
\end{array}$ & $\begin{array}{l}2.25325 * * \\
(0.988234)\end{array}$ & $\begin{array}{l}-0.265027 \\
(0.472803)\end{array}$ \\
\hline Long rains dummy & $\begin{array}{l}-2.62665 * * * \\
(0.830993) \\
\end{array}$ & $\begin{array}{l}6.99441 * * \\
(2.91198) \\
\end{array}$ & $\begin{array}{l}-0.982315 * \\
(0.531057)\end{array}$ & $\begin{array}{l}0.727057 * * \\
(0.313390) \\
\end{array}$ \\
\hline Short rains dummy & $\begin{array}{l}-1.41195 * * \\
(0.691896)\end{array}$ & $\begin{array}{l}6.86842 * * \\
(2.72092)\end{array}$ & $\begin{array}{l}1.93220 * * * \\
(0.632559)\end{array}$ & $\begin{array}{l}-0.145927 \\
(0.367714)\end{array}$ \\
\hline Age Male & $\begin{array}{l}-0.545024 * \\
(0.317679)\end{array}$ & $\begin{array}{l}0.141995 \\
(0.452050)\end{array}$ & $\begin{array}{l}0.332280 \\
(0.495973)\end{array}$ & $\begin{array}{l}-0.170201 \\
(0.153673) \\
\end{array}$ \\
\hline Age Male squared $\left(\times 10^{-2}\right)$ & $\begin{array}{l}0.043025 \\
(0.031656)\end{array}$ & $\begin{array}{l}-0.018652 \\
(0.0332815)\end{array}$ & $\begin{array}{l}-0.620450 * * * \\
(0.209520)\end{array}$ & $\begin{array}{l}0.244827 * * * \\
(0.0826743)\end{array}$ \\
\hline Age Female & $\begin{array}{l}-1.05158 \\
(0.795533) \\
\end{array}$ & $\begin{array}{l}0.767702 * * * \\
(0.0459241) \\
\end{array}$ & $\begin{array}{l}-0.533905 * \\
(0.296713)\end{array}$ & $\begin{array}{l}0.388611 * * * \\
(0.0648671) \\
\end{array}$ \\
\hline Age Female squared $\left(\times 10^{-2}\right)$ & $\begin{array}{l}0.0471570 \\
(0.0325210)\end{array}$ & $\begin{array}{l}-0.039773 \\
(0.024708) \\
\end{array}$ & $\begin{array}{l}0.449019 \\
(0.279974)\end{array}$ & $\begin{array}{l}-0.343793 * * * \\
(0.0813718)\end{array}$ \\
\hline Scaling RE term & $\begin{array}{l}-2.84894 * * * \\
(0.0 .439853)\end{array}$ & $\begin{array}{l}1.64785 * * * \\
(0.516992)\end{array}$ & $\begin{array}{l}1.97078 * * * \\
(0.370397) \\
\end{array}$ & $\begin{array}{l}1.54897 * * * \\
(0.504720)\end{array}$ \\
\hline Sigma & $\begin{array}{l}7.55850 * * * \\
(0.229534)\end{array}$ & $\begin{array}{l}4.6299 * * * \\
(1.98341)\end{array}$ & $\begin{array}{l}4.91338 * * * \\
(0.177469)\end{array}$ & $\begin{array}{l}2.13608 * * * \\
(0.346717)\end{array}$ \\
\hline Covariance & $\begin{array}{l}8.80232 \\
(11.5398) \\
\end{array}$ & & $\begin{array}{l}-7.57171 * * * \\
(0.890904)\end{array}$ & \\
\hline Male Age Joint $\chi_{(2)}^{2}$ & 0.3 & 1.5 & $11.0 * * *$ & $8.8 * *$ \\
\hline Female Age Joint $\chi_{(2)}^{2}$ & 0.5 & $7.24 * *$ & 3.5 & $44.6 * * *$ \\
\hline Household means joint $\chi_{(4)}^{2}$ & $16.1 * * *$ & $8.4 *$ & $12.2 * *$ & $34.7 * * *$ \\
\hline $\mathrm{LnL}$ & & 46.4 & & 92.46 \\
\hline Number of observations & & 31 & & 632 \\
\hline
\end{tabular}


Table 4. SFIML Simultaneous Tobit Estimation of Distance from Town and Milk Sales.

\begin{tabular}{|c|c|c|c|c|}
\hline & \multicolumn{2}{|c|}{ Dukana } & \multicolumn{2}{|c|}{ Chalbi } \\
\hline & Distance & Milk Sales $\left(\mathrm{x} 10^{-2}\right)$ & Distance & Milk Sales $\left(\mathrm{x} 10^{-3}\right)$ \\
\hline Milk sales & $\begin{array}{l}3.16611 * * * \\
(1.02678)\end{array}$ & & $\begin{array}{l}3.70025 * * * \\
(0.25908)\end{array}$ & \\
\hline Distance & & $\begin{array}{l}-0.658005 \\
(0.597104)\end{array}$ & & $\begin{array}{l}-0.686938 * * * \\
(0.250100) \\
\end{array}$ \\
\hline Number of pack camels & $\begin{array}{l}-0.597525 \\
(0.700377)\end{array}$ & & $\begin{array}{l}-0.148756 \\
(0.341006)\end{array}$ & \\
\hline Raid dummy & $\begin{array}{l}-0.00467 \\
(0.080205)\end{array}$ & & $\begin{array}{l}-0.157237 \\
(0.678321)\end{array}$ & \\
\hline Age Male & $\begin{array}{l}-1.60016 * * * \\
(0.405667)\end{array}$ & & $\begin{array}{l}-0.114330 \\
(0.0903741)\end{array}$ & \\
\hline Age Male squared $\left(\times 10^{-2}\right)$ & $\begin{array}{l}0.0481240 * \\
(0.0279672)\end{array}$ & & $\begin{array}{l}-0.327497 * * * \\
(0.120488)\end{array}$ & \\
\hline $\begin{array}{l}\text { Average milk sales by others } \\
\left(\times 10^{-3}\right)\end{array}$ & & $\begin{array}{c}1.21607 \\
(1.31930) \\
\end{array}$ & & $\begin{array}{l}1.05392 \\
(0.66353) \\
\end{array}$ \\
\hline Age Female & & $\begin{array}{l}0.759154 \\
(1.11347)\end{array}$ & & $\begin{array}{l}0.057281 \\
(0.07209) \\
\end{array}$ \\
\hline Age Female squared $\left(\times 10^{-2}\right)$ & & $\begin{array}{l}-0.0459006 \\
(0.0288405)\end{array}$ & & $\begin{array}{l}-0.029279 \\
(0.072929)\end{array}$ \\
\hline Constant & $\begin{array}{l}12.2803 \\
(10.7371)\end{array}$ & $\begin{array}{l}-17.8559^{* *} \\
(8.16485)\end{array}$ & $\begin{array}{l}-8.05165^{* *} \\
(3.45926)\end{array}$ & $\begin{array}{l}-2.20547 \\
(1.93031)\end{array}$ \\
\hline Distance last period & $\begin{array}{l}0.458494 * * * \\
(0.0357006)\end{array}$ & $\begin{array}{l}0.200812 \\
(0.158266)\end{array}$ & $\begin{array}{l}0.458468 * * * \\
(0.0553490)\end{array}$ & $\begin{array}{l}-0.117103 * * \\
(0.058656)\end{array}$ \\
\hline Sales last period & $\begin{array}{l}0.951257 * * \\
(0.435340)\end{array}$ & $\begin{array}{l}0.196624 \\
(1.18545)\end{array}$ & $\begin{array}{l}-1.36179 * * * \\
(0.311567)\end{array}$ & $\begin{array}{l}0.740558 * * * \\
(0.166458)\end{array}$ \\
\hline Herd size in TLU $\left(\times 10^{-1}\right)$ & $\begin{array}{l}-0.9902040 \\
(0.822048)\end{array}$ & $\begin{array}{c}1.45691 \\
(1.23312)\end{array}$ & $\begin{array}{l}0.0976145 \\
(0.235259)\end{array}$ & $\begin{array}{l}0.004418 \\
(0.169209)\end{array}$ \\
\hline $\begin{array}{l}\text { Household size in adult } \\
\text { equivalents }\end{array}$ & $\begin{array}{l}1.97146 * * \\
(0.879839)\end{array}$ & $\begin{array}{l}3.18593 \\
(2.47187) \\
\end{array}$ & $\begin{array}{l}-1.27893 \\
(1.01103) \\
\end{array}$ & $\begin{array}{l}0.346612 * * \\
(0.162650) \\
\end{array}$ \\
\hline Food aid in tons $\left(\times 10^{-2}\right)$ & $\begin{array}{l}-1.14117 * * * \\
(0.414120)\end{array}$ & $\begin{array}{l}1.08195 \\
(1.06367)\end{array}$ & $\begin{array}{l}-6.26452 * * * \\
(1.63783)\end{array}$ & $\begin{array}{l}-1.95668 \\
(1.53858)\end{array}$ \\
\hline $\begin{array}{l}\text { Rainfall in } \mathrm{mm} \text { in past six } \\
\text { months }\left(\times 10^{-2}\right)\end{array}$ & $\begin{array}{l}-0.099194 \\
(0.546279)\end{array}$ & $\begin{array}{r}0.704351 \\
(2.33609)\end{array}$ & $\begin{array}{l}2.10473 * * * \\
(0.692972)\end{array}$ & $\begin{array}{l}-0.00158 \\
(0.18819) \\
\end{array}$ \\
\hline Long rains dummy & $\begin{array}{l}-2.64453 * * * \\
(0.985721)\end{array}$ & $\begin{array}{l}7.33979 * \\
(3.97177)\end{array}$ & $\begin{array}{l}-0.967397 * \\
(0.526434)\end{array}$ & $\begin{array}{l}0.774157 * * \\
(0.400687)\end{array}$ \\
\hline Short rains dummy & $\begin{array}{l}-1.43078 \\
(0.955378)\end{array}$ & $\begin{array}{l}7.22790 * \\
(4.25104)\end{array}$ & $\begin{array}{l}1.91526 * * \\
(0.888379)\end{array}$ & $\begin{array}{l}-0.035171 \\
(0.957286)\end{array}$ \\
\hline Scaling RE term & $\begin{array}{l}-2.85106 * * * \\
(0.453921)\end{array}$ & $\begin{array}{l}1.63210^{* *} \\
(0.782943)\end{array}$ & $\begin{array}{l}2.00160 * * * \\
(0.400190)\end{array}$ & $\begin{array}{l}1.80756 * * \\
(0.774466)\end{array}$ \\
\hline Sigma & $\begin{array}{l}7.54423 * * * \\
(0.270483)\end{array}$ & $\begin{array}{l}4.95976 \\
(3.30215)\end{array}$ & $\begin{array}{l}4.92100 * * * \\
(0.181131)\end{array}$ & $\begin{array}{l}2.24230 * * * \\
(0.376620)\end{array}$ \\
\hline Covariance & $\begin{array}{l}11.0787 \\
(25.2866)\end{array}$ & & $\begin{array}{l}-7.61454 * * * \\
(1.15797)\end{array}$ & \\
\hline Male Age Joint $\chi_{(2)}^{2}$ & $25.1 * * *$ & & $12.3 * * *$ & \\
\hline Female Age Joint $\chi_{(2)}^{2}$ & & 4.5 & & $5.8 *$ \\
\hline Household Means Joint $\chi_{(4)}^{2}$ & $23.3 * * *$ & 7.2 & $15.5 * * *$ & $20.1 * * *$ \\
\hline $\mathrm{LnL}$ & & 6.91 & & 993.81 \\
\hline Number of observations & & 31 & & 632 \\
\hline
\end{tabular}


Table 5. First Difference Fixed Effects Estimation of Milk Production in Liters Per Day

\begin{tabular}{|c|c|c|}
\hline & Dukana & Chalbi \\
\hline Constant & $\begin{array}{l}-1.62334 * * * \\
(0.25398)\end{array}$ & $\begin{array}{l}-2.17184 * * * \\
0.36791\end{array}$ \\
\hline Herd Size in TLU & $\begin{array}{l}0.16528 * * * \\
(0.04032)\end{array}$ & $\begin{array}{l}0.018311^{* * * *} \\
(0.00112)\end{array}$ \\
\hline Herd Size in $\operatorname{TLU}^{2}\left(\times 10^{-2}\right)$ & \begin{tabular}{|c|}
0.00055 \\
$(0.00082)$ \\
\end{tabular} & $\begin{array}{l}0.000111^{* * *} \\
(0.00002)\end{array}$ \\
\hline Distance in hours from town & $\begin{array}{l}-0.04618 \\
(0.02890)\end{array}$ & $\begin{array}{c}0.01972 \\
(0.04431)\end{array}$ \\
\hline Distance in hours from town ${ }^{2}$ & $\begin{array}{l}0.001566^{*} \\
(0.00081)\end{array}$ & \begin{tabular}{|l|}
-0.00032 \\
$(0.00130)$
\end{tabular} \\
\hline Fraction at Satellite camp & \begin{tabular}{|l|}
-0.11024 \\
$(0.30812)$
\end{tabular} & $\begin{array}{l}-0.43618 * * \\
(0.17863)\end{array}$ \\
\hline Rainfall in past six months & \begin{tabular}{|c|}
0.00424 \\
$(0.00358)$ \\
\end{tabular} & $\begin{array}{l}0.00766 * * * \\
(0.00264) \\
\end{array}$ \\
\hline Rainfall in past six months ${ }^{2}\left(\mathrm{x} 10^{-3}\right)$ & \begin{tabular}{|l|}
-0.01038 \\
$(0.01918)$ \\
\end{tabular} & $\begin{array}{l}-0.000290 \text { *** } \\
(0.00011)\end{array}$ \\
\hline Long Rains Dummy & $\begin{array}{l}2.35465 * * * \\
(0.14122)\end{array}$ & $\begin{array}{l}1.24280 * * * \\
(0.22212)\end{array}$ \\
\hline Short Rains Dummy & $\begin{array}{l}1.37542 * * * \\
(0.13088) \\
\end{array}$ & $\begin{array}{l}0.47704 * * \\
(0.20147) \\
\end{array}$ \\
\hline Time trend & $\begin{array}{l}0.16034 * * * \\
(0.05027)\end{array}$ & $\begin{array}{l}0.46463 * * * \\
(0.07266)\end{array}$ \\
\hline Time trend ${ }^{2}\left(\times 10^{-2}\right)$ & $\begin{array}{l}-0.856211^{* * *} \\
(0.25284)\end{array}$ & $\begin{array}{l}-2.65219^{* * *} \\
(0.37309)\end{array}$ \\
\hline Herd joint significance $\chi_{(2)}^{2}$ & $176.0 * * *$ & $341.6 * * *$ \\
\hline Distance joint significance $\chi_{(2)}^{2}$ & $3.7 *$ & 0.3 \\
\hline $\mathrm{R}^{2}$ & 0.38 & 0.68 \\
\hline Number of Observations & 980 & 687 \\
\hline
\end{tabular}




\section{References:}

Attanasio, Orazio and Valerie Lechene. "Tests of income pooling in household decisions." Review of Economic Dynamics 5 (2002): 720-748.

Blundell, R., P. Chaippori, T. Magnac and C. Meghir. Collective labor supply: Heterogeneity and nonparticipation. Mimeo. University College London, Department of Economics, London. (2002)

Bekure, S., P. de Leeuw, B. Grandin, P. Neaate. Maasai Herding. ILCA systems study \#4. International Livestock Center for Africa. Addis Ababa, Ethiopia. (1991)

Coppock, D.L. The Borana Plateau of Southern Ethiopia: Synthesis of pastoral research, development and change, 1980-91. ILCA systems study \#5. International Livestock Centre for Africa, Addis Ababa, Ethiopia. (1994)

Dercon, S. and P. Krishnan. "In Sickness and in health: Risk sharing within households in rural Ethiopia." Journal of Political Economy 108 (2000): 688-727.

Dey, J. “Gambian Women: Unequal Partners in Rice Development Projects?” Journal of Development Studies 17 (1981): 109-22.

Doss, C.R. "Intra-household Resource Allocation in Ghana: The Impact of the Distribution of Asset Ownership within the Household." In G.H. Peters and J. von Braun, eds.. Food security, diversification and resource management: Refocusing the role of agriculture? Proceedings of the Twenty-third International Conference of Agricultural Economists held at Sacramento, California, 10-16 August 1997. Aldershot, U.K. and Brookfield, Vt.: Ashgate, (1999) pp. 309-16.

Doss, C.R. "Is risk fully pooled within the household? Evidence from Ghana." Economic Development and Cultural Change, 50 (2001):101-130.

Ensminger, J. "Economic and Political Differentiation among Galole Orma women." Ethnos. 52 (1987): 28-49.

Fratkin, E., E. Roth, and M. Nathan. "When Nomads Settle: the effects of commoditization, nutritional change, and formal education on Ariaal and Rendille pastoralists." Current Anthropology 40 (1999): 729-735

Fratkin, E. Ariaal Pastoralists of Kenya. Pearson: Boston. (2004)

Gourieroux, C. and A. Monfort. "Simulation-Based Inference: a survey with special reference to panel data models." Journal of Econometrics. 59 (1993): 5-33. 
Hallman, K. Mother-Father resource control, marriage payments, and girl-boy health in rural Bangladesh. Food Consumption and Nutrition Division Discussion Paper No. 93, International Food Policy Research Institute, Washington, DC. (2000)

Herren, U.J. "Cash from camel milk." Nomadic Peoples 30 (1991) :97-113.

Hoddinott, J. and L. Haddad. "Does female income share influence household expenditures? Evidence from Cote D'Ivoire." Oxford Bulletin of Economics and Statistics 57 (1995): 77-96.

Holden, S. and D.L Coppock. "Effects of distance to market, season and family wealth on pastoral dairy marketing in Ethiopia." Journal of Arid Environments 23 (1992):321-334.

Holden, S., D.L. Coppock, and M. Assefa. "Pastoral Dairy Marketing and Household Wealth Interactions and their Implications for Calves and Humans in Ethiopia." Human Ecology. 19 (1991): 35-59.

Hsiao, C. Analysis of Panel Data. Cambridge, Cambridge University Press. (1986)

Jones, C. 1983. "The mobilization of women's labor for cash crop production: A game theoretic approach." American Journal of Agricultural Economics: (1983) 1049-1054.

Laferrere, A. “Marriage settlements.” Scandinavian-Journal-of-Economics 103 (2001): 485-504.

Lundberg, S., R.A. Pollak and T.J. Wales. "Do husbands and wives pool their resources? Evidence from the U.K. child benefit." Journal of Human Resources 32 (1997): 463-80.

Lundberg, S. and J. Ward-Batts. Saving for retirement: Household bargaining and household net worth. Discussion Paper 0026, Department of Economics, University of Washington. (2000)

Lundberg, S., R. Startz, and S. Stillman. “A marital bargaining approach.” Journal of Public Economics 87(2003): 1199-1218.

Maddala, G.S. Limited-Dependent and Qualitative Variables in Econometrics. Cambridge, Cambridge University Press (1983)

Martin, M. "Design of a food intake study in two Bambara villages in the Segou Region of Mali with preliminary findings." in A. Hill ed., Population, Health and Nutrition in the Sahel. A. Hill ed. London, KPI Limited. (1985)

Michael, B. "Milk Production and Sales by the Hawazma (Baggara) of Sudan: Implications for Gender Roles." Research in Economic Anthropology. 9 (1987):105-141.

McPeak, J. "Analyzing and Addressing Localized Degradation in the Commons." Land Economics. 79 (2003): 515-536. 
Ndagala, D. "Operation Imparnati: the sedentarization of the pastoral Maasai in Tanzania." Nomadic Peoples. 10 (1982):28-39

Nduma, I., P. Kristjanson, and J. McPeak. "Diversity in Income-Generating Activities for Sedentarized Pastoral Women in Northern Kenya." Human Organization. 60 (2001): 319-325.

Quisumbing, A. and J. Maluccio. "Resources at marriage and intrahousehold allocation: Evidence from Bangladesh, Ethiopia, Indonesia, and South Africa." Oxford Bulletin of Economics and Statistics, 65 (2003): 283-327.

Robinson, P. Gabra Nomadic Pastoralism in Nineteenth and Twentieth Century Northern Kenya: Strategies for Survival in a Marginal Environment. Unpublished Ph.D. Dissertation. Northwestern University, Department of History. (1985)

Schwartz, H.J., S. Shaabani and D. Walther Eds. Range Management Handbook of Kenya. Nairobi, Republic of Kenya, Ministry of Livestock Development. (1991)

Sikana, P. and C. Kerven. The impact of commercialization on the role of labor in African pastoral societies. Pastoral Development Network, ODI, London. Paper 31c. (1991)

Tablino, P. The Gabra: Camel Nomads of Northern Kenya. Paulines Publications Africa: Limuru, Kenya (1999)

Thomas, D. "The distribution of income and expenditure within the household." Annales d'Economie et de Statistique 29(January/March 1993) 109-136.

Thomas, D. and C. Chen. Income shares and shares of income: Empirical tests of models of household resource allocations. Mimeo .Santa Monica, CA: RAND. (1993)

Thomas, D., D. Contreras, and E. Frankenberg. Distribution of power within the household and child health. Mimeo. Los Angeles, CA: UCLA.(2002)

Torry, W. Subsistence Ecology Among the Gabra: Nomads of the Kenya / Ethiopia Frontier. Unpublished Ph.D. Dissertation. Columbia University, Department of Anthropology. (1973)

Turner M. "Changing uses of wealth stores by rural smallholders: Description of an approach used for the longitudinal analysis of livestock transactions in the Sahel." In: Ehui S.K., Lynam J. and Okike I. (eds), Adapting social science to the changing focus of international agricultural research. Proceedings of a Rockefeller Foundation-ILCA Social Science Research Fellows workshop, 14-18 November 1994, held at ILCA, Addis Ababa, Ethiopia. ILCA (International Livestock Centre for Africa), Addis Ababa, Ethiopia. (2003) pp. 189-203. 
Udry, C. "Gender, agricultural production, and the theory of the household." Journal of Political Economy 104 (1996): 1010-1046.

USAID. USAID Agriculture Strategy: Linking Producers to Markets. PD-ABZ-800. United States Agency for International Development: Washington, DC. (July 2004).

USAID. Nature, Wealth, and Power: Emerging Best Practice for Revitalizing Rural Africa. United States Agency for International Development: Washington, DC. (August 2002).

von Braun, J., and P.J.R. Webb. "The impact of new crop technology on the agricultural division of labor in a West African setting." Economic Development and Cultural Change 37 (1989): 513-34.

Waters-Bayer, A. Dairying by settled Fulani women in central Nigeria and some implications for dairy development. Pastoral Development Network, ODI, London. Paper 20c. (1985)

World Bank. World Development Report 2002: Building Institutions for Markets. World Bank, Washington DC. (2001)

\section{Notes}

${ }^{1}$ In this paper, we do not try to distinguish among different types of cooperative outcomes, such as the joint cooperative solution and the individual solution. Much of the intrahousehold literature has focused on determining which cooperative outcome results, based on bargaining power or other factors. We model the joint cooperative solution, and note that the individual solution is a special case of it.

${ }^{2}$ A unitary model assumes that the household acts as though there is one decision-maker. Bargaining models explicitly note that there may be more than one decision-maker and that the decision makers may have different preferences. These may affect the outcomes.

${ }^{3}$ A separate theme in the literature is intra-household household decision making with regard to supplying labor. Two studies extend Chiappori's (1988) collective model of labor supply to examine censoring and nonparticipation in employment (Blundell et al., 2002) and marriage 
markets and divorce (Chiappori et al., 2002). Again, studies on this theme tend to support the assumption that household decision making is cooperative.

${ }^{4}$ Two different themes in the literature on milk marketing merit note. First, it is frequently found that milk marketing is a function of wealth as represented by herd size (Nduma et al. 2001; Herren, 1992; Holden et al. 1991) and that milk marketing is a function of household distance to market (Holden and Coppock, 1992). Our focus in this study also builds on the latter theme.

${ }^{5}$ Migration decisions are occasionally taken by a collection of households jointly residing at a camp, but each household has the right to break away and join another camp, settle on their own, or remain where they are and perhaps be joined by other households. As camp composition is changes over time, the ultimate decision making authority over migration decisions rests with the eldest male in the household.

${ }^{6}$ The definition of this sample did not include former herders who have moved to the small towns of the study area, either in search of economic opportunities or due to the loss of their herd. Issues of selection bias are possible if herders who lost their animals between 1992 and 1997 were systematically overlooked due to the sampling method based on the outcome of herders still residing in the grazing areas. However, discussion with both nomads and town residents indicated this was not likely to be a major issue, as there was not a significant population flow from the rangelands into the towns during this time period, and very few households were forced out of pastoralism due to the herd losses experienced in 1996. 
${ }^{7}$ Respondents appeared to have little difficulty in recalling season-specific information over the four year time period covered in this study. This was likely aided by the fact that widespread herd losses in 1992 served as a notable starting period. In addition, herd genealogies were constructed for camels and cattle to record livestock production information, and served as the foundation for other questions (for a discussion of this methodology, see Turner, 2003). In a society where records are not written, information contained in herders' memories serves a critical function in herd management decisions. Knowledge of complicated genealogy structures and historical events is critical for both Gabra society and for herd management decisions (Tablino, 1999; Robinson, 1985; Torry, 1973). While repeated observations would be preferable for construction of a longitudinal data set, the recall data in this study is internally consistent, and is in our judgment reliable enough to analyze empirically.

${ }^{8}$ Work began in Chalbi before Dukana, so the number of observations per household in Dukana tends to be greater than that for Chalbi. Not all observations are used directly in the estimations reported below, as some observations are used to construct lagged variables, and a few observations in Chalbi had to be omitted due to missing variables ${ }^{9}$ In caloric terms, this corresponds to an average of 3268 calories per person per day in Chalbi and 1202 calories per person per day in Dukana. Note neither the income variable nor the calorie variable includes the value of food aid. Although we did not collect food aid receipt data per household, we can estimate the contribution by noting that food aid when distributed in this area often works with a target level of 10 kilograms of grain per person per month - which would generate roughly 1,500 more calories per day. Food aid was distributed in $70 \%$ of time periods observed. 
${ }^{10}$ This is the milk produced for human consumption. Traditionally, half the udder of a milking animal is taken for human consumption and the other half is left for young stock to suckle.

11 The adult equivalent weighting scheme used in this study assigns a value of one to individuals of both sexes older than 15, a value of .6 to individuals 6-14 years old, a value of .3 to children ages 2-5, a value of . 1 for children under 2.

${ }^{12}$ One livestock unit $=10$ sheep or goats $=1$ head of cattle $=0.7$ camels. This differs slightly from the scheme in Schwartz et al. as they weigh 11 goats equal to one TLU. As the data set records the total number of sheep and goats combined, this composite measure of smallstock is assigned a weight of 1 animal $=0.1$ TLU.

${ }^{13}$ The rainfall and food aid records were provided by the Catholic mission in North Horr and the AIC mission in Kalacha.

${ }^{14}$ While the focus of this paper is the dynamic process of cultural adaptation to market development, we develop our argument through models that generate outcomes for different states of this process as separate static models rather than through use of a unified dynamic model. This keeps the model as simple as possible while illuminating our main points. We leave as a future extension the connection of these different phases in a unified dynamic model.

${ }^{15}$ For simplicity, we assume a household in our model is only composed of a husband and a wife. 
${ }^{16}$ Within the models, outcomes would differ depending on the weights assigned to consumption in each person's utility. But changing the weights does not affect the sign on the response of distance to milk sales, which is our main concern in this paper.

${ }^{17}$ For simplicity we specify weights and values in our models as parameters to focus on outcomes. The model could be extended to view the weights and values themselves as an outcome of a negotiation process, but we leave that as a further refinement.

${ }^{18}$ In reality, there are other goods that are consumed, such as meat from the herd, goods purchased with the proceeds of livestock sales. Husbands do make decisions about livestock sales and slaughters that we abstract from here to focus on milk sales.

${ }^{19}$ There is a positive caloric terms of trade for milk and grains in this area, as the equivalent cash value of milk and grain provides around 6 times more caloric value when in the form of grain, so on way to interpret $\theta$ in that it equals 6 in caloric terms. This is a limited, but simple way of interpreting the relative "value" in consumption of home consumed milk and goods purchased with milk sales proceeds.

${ }^{20}$ We model the disutility of milk sales arising in the reduced milk available for the husband's consumption. In our field work, we heard wives advance the story that milk sales enhance household welfare overall, as they provide food and clothing for themselves and the children with this income, while still leaving enough milk for the family. However, we also had husbands propose that when women gain control over income they will spend it on private goods thus depriving the household of both milk and income from milk sales. Interestingly, discussions 
with Gabra husbands suggested that there was also a fear that a wife would spend money on town based boyfriends, echoed by Fratkin (20034) who quotes a woman from the neighboring Ariaal group reflecting on issues of women's control over income saying “...some men oppose their wives to work for money, maybe they think we will overlook them and become proud, or we might leave them and go away with another man. With some people, this will happen.” (p. 128). Here we just model it as women gaining control of the income, without considering how it is spent.

${ }^{21}$ Data limitations do not allow us to investigate whether distance is influenced by the value of $\eta$. We could not reliably record expenditure information on milk sales proceeds to categorize it into personal consumption for the wife versus a contribution to shared household consumption, though this is a promising topic for future research.

${ }^{22}$ Milk purchasers are generally town -based households who do not have significant livestock holdings. The milk sellers are pastoral nomads.

${ }^{23}$ Although as noted above most households sold milk during at least one of the periods of the survey, only one of the 88 households surveyed sold milk in each period recorded, suggesting this is an activity households enter and exit over time.

${ }^{24}$ Four variables are constructed to control for the household specific fixed effect: average household herd size, average household size in adult equivalents, average age of the oldest male, and average age of the oldest female. 
25 The parameters for the age and age squared of the oldest female are not jointly significant in the distance equation for Dukana or Chalbi. The parameters for the age and age squared of the oldest male are not jointly significant in the milk sales equation for Dukana but are jointly significant in Chalbi. The relative age of men and women is often considered a measure of bargaining power. For example, Lundberg, et al, 2003, Laferrere 2001, and Lundberg and WardBatts, 2000.

${ }^{26}$ Dukana $\left(\chi_{(7)}^{2}=22.5 * * *\right)$ and Chalbi $\left(\chi_{(7)}^{2}=20.1 * * *\right)$ 